AperTO - Archivio Istituzionale Open Access dell'Università di Torino

\title{
Current account imbalances, trade and finance
}

\section{This is the author's manuscript}

Original Citation:

Availability:

This version is available http://hdl.handle.net/2318/93369

since 2016-09-13T16:17:02Z

Published version:

DOI:10.1080/13504851.2011.581198

Terms of use:

Open Access

Anyone can freely access the full text of works made available as "Open Access". Works made available under a Creative Commons license can be used according to the terms and conditions of said license. Use of all other works requires consent of the right holder (author or publisher) if not exempted from copyright protection by the applicable law. 


\section{(0) \\ UNIVERSITÀ DEGLI STUDI DI TORINO}

This is an author version of the contribution published on:

Applied Economics Letters, volume 19, issue 4, March 2012, pages 399-402

The definitive version is available at:

http://www.tandfonline.com/doi/abs/10.1080/13504851.2011.581198\#.UxnnwfWYa70 


\title{
Current account imbalances, trade and finance
}

\author{
Anna Lo Prete \\ Department of Economics, University of Turin, Via Po 53, 10124 Torino (TO), Italy \\ E-mail address: anna.loprete@unito.it
}

\section{Running head}

Current account imbalances, trade and finance

\begin{abstract}
This paper analyses how trade-related policy choices and financial development affect current account imbalances in OECD countries. Once the policy-related component of trade openness is estimated using exogenous-to-policy indicators of globalization pressures, legal origins and natural openness, financial development plays a significant role and is negatively associated with the current account.
\end{abstract}




\section{Introduction}

Empirical studies on medium-term determinants of current account imbalances explore the pattern of external balances accounting for the role of openness and financial development along with other potential determinants of current account imbalances. Following the seminal paper by Chinn and Prasad (2003), empirical specifications include openness indicators to capture two dimensions of macroeconomic policy: 'trade openness' relates to tariff regimes and other policy choices relevant to economic integration; 'financial openness' captures the effect of liberalization policies occurring in financial markets and affecting cross-country capital flows. Whether these variables are positively or negatively associated with the current account is mainly an empirical question. The same is true for 'financial development': it may affect the current account positively or negatively depending on whether financial sophistication spurs savings, or lessens borrowing constraints (see the discussion in Chinn and Ito, 2008b).

Empirically, it seems difficult to identify a stable association between the current account balance and indicators of openness or financial development. Recent papers show that they are mainly relevant once interacted with other indicators of financial crises (Gruber and Kamin, 2007) and environmental factors (Chinn and Ito, 2008b). Of course, a potential issue in cross-country comparison is data quality. In this context, for instance, while 'de jure' measures may well fit the purpose of controlling for liberalization policies, economic integration policy choices are usually proxied by a catch-all measure, the openness (i.e. imports plus exports) to GDP ratio.

This paper proposes to identify the policy component of trade openness using exogenousto-policy indicators of globalization pressures, legal origins and natural openness, and shows that this approach conveys a clear message on the role of trade-related policies and financial development as current accounts' determinants. In a panel of 19 OECD countries 
observed between 1980 and 2007, economic integration policies have a positive effect on the current account, financial development significantly decreases it.

\section{Empirical specification}

To estimate the policy-related component of trade openness, this paper adapts the empirical strategy of Bertola and Lo Prete (2010), who identify in geographical characteristics, remote historical events, and their interaction with exogenous globalization trends a set of exogenous to policy determinants of economic integration. In the present analysis, "policy openness' is accordingly defined as the residual component from a specification where the openness ratio to GDP, a standard indicator of economic integration from the Penn World Tables, is regressed on several variables which are likely related to economic integration, but not related to policy choices: the 'natural openness' indicator by Frankel and Romer (1999), 'legal origin' dummies by La Porta et al. (1999), and a time-varying indicator of the intensity of global trade (defined in Appendix A). The openness equation reads:

$$
\mathrm{OP}_{\mathrm{jt}}=\alpha_{0}+\alpha_{1} \mathrm{NatOP}_{\mathrm{j}}+\alpha_{2} \mathrm{WT}_{\mathrm{t}}+\alpha_{3} \mathrm{G}_{\mathrm{jt}}+\alpha_{4}\left(\mathrm{G}_{\mathrm{jt}} * \mathrm{~L}_{\mathrm{j}}\right)+\mathrm{L}_{\mathrm{j}} \Gamma+\varepsilon_{\mathrm{jt}}
$$

where the $G_{j t}$ indicator is a measure of Globalization pressures given by the product of World Trade $\left(W T_{t}\right)$ and Natural Openness $\left(N a t O P_{j}\right)$. And its interaction with Legal Origin dummies $\left(L_{j}\right)$ accounts for the fact that the intensity of globalization pressures affects trade openness $\left(O P_{j t}\right)$ differently in countries more or less market friendly due to historical events mirrored by their legal systems' origin.

Once the policy openness indicator is computed using residuals from equation (1), it is possible to compare its explanatory power, as a determinant of current account imbalances, with that of the openness to GDP ratio. The current account balance to GDP ratio is the dependent variable in the specification 


$$
\mathrm{CA} / \mathrm{GDP}_{\mathrm{jt}}=\alpha_{0}+\mathrm{X}_{\mathrm{jt}} \Gamma+\mathrm{O}_{\mathrm{jt}} \Lambda+\alpha_{1} \text { FinDev }_{\mathrm{jt}}+\varepsilon_{\mathrm{jt}}
$$

where $\mathrm{X}_{\mathrm{jt}}$ is a set of standard macroeconomic variables including the government budget balance to GDP ratio, the stock of initial net foreign assets (NFA) divided by GDP, indicators of demographic structure (the old and young dependency ratios), relative income levels and their square terms, average GDP growth, and terms of trade volatility (data sources are reported in Appendix A). $\mathrm{O}_{\mathrm{jt}}$ includes the Chinn and Ito (2008a) indicator of financial openness, and alternative measures of economic integration policies. Finally, financial development $\left(\right.$ FinDev $\left._{\mathrm{jt}}\right)$ is measured by the ratio of private credit to GDP. Equation (2) is estimated for a balanced panel of 19 OECD countries observed over the period 1980-2007. To control for cyclicality and focus on medium-term variations, as in Chinn and Ito (2008b) and Gruber and Kamin (2007), data are averaged over five-year non overlapping sub-periods; and all explanatory variables but NFA to GDP are expressed in relative terms, as deviations from GDP-weighted sample averages.

\section{Empirical results}

Results not reported indicate that regressors in equation (1) are jointly significant and explain $65 \%$ of trade openness variation. Estimates from equation (2) are in Table 1 and help assessing the explanatory power of openness and finance indicators. The first four columns show that, adding openness and finance indicator individually to the set of control variables, trade openness has a positive impact on the current account (column 1), financial openness has no statistically significant explanatory power (column 2), and financial development exerts a negative effect. The effect of financial development is marginally significant when controlling also for financial openness (column 5); it is not precisely estimated in specifications including trade openness (columns 6 and 7). The policy openness indicator is less correlated with financial development (see Table A.1), and conveys a clearer message: policies that are conducive to more economic integration are 
positively associated with the current account, while more financial development tends to worsen it (column 9). These findings support the argument that financial development implies better international diversification opportunities and lessens precautionary saving motives (Bernanke, 2005). Column (10) shows that the component of trade openness estimated from equation (1), 'non-policy openness', is not statistically significant and reduces the explanatory power of financial development. As to the other control variables, terms of trade volatility, old dependency ratios, and relative income are positively correlated with current account imbalances. Results are robust when time dummies allow the current account to record a different value in each sub-period (regressions not reported).

\section{Conclusions}

This paper proposes an empirical approach to estimate the policy-related component of openness. It focuses on the role of openness and finance indicators as medium-run determinants of current account imbalances in OECD countries, and shows that while the openness ratio to GDP is an imperfect measure of macroeconomic policies that is correlated with indicators of financial development, controlling for policy openness allows to estimate more precisely the effect of financial development.

\section{Appendix A. Data sources}

The panel is balanced with respect to the variables used to estimate equations (1) and (2), and includes 19 OECD countries, from 1980 to 2007, namely: Australia, Belgium, Canada, Denmark, France, Greece, Iceland, Ireland, Israel, Italy, Japan, New Zealand, Norway, Portugal, South Korea, Spain, Sweden, United Kingdom, United States. Data are averaged over six sub-periods including five years each (three in the last one, 2005-2007).

World Trade is the share of global trade (exports plus imports) as a percentage of global GDP, computed using data from the Penn World Tables for all the countries for which information on trade openness is available in all years between 2005-07. Financial 
development is the variable 'Private Credit by Deposit Money Banks and Other Financial Institutions to GDP' from the World Bank's Financial Development and Structure Database (May 2009 issue). The financial openness indicator is adjusted to range between zero and positive values. Macroeconomic variables in $\mathrm{X}_{\mathrm{jt}}$ are drawn by the Penn World Tables (Version 6.3), the IMF World Economic Outlook (April 2008 issue), the World Bank's World Development Indicators online database (April 2009 issue).

\section{References}

Bernanke, B. (2005) The Global Saving Glut and the U.S. Current Account. Remarks at the Sandridge Lecture, Virginia Association Of Economics (Richmond, Virginia).

Bertola, G., and Lo Prete, A. (2010) Whence Policy? Government Policies, Finance, and Economic Integration, CEPR Discussion Paper 7820.

Chinn, M.D., and Ito, H. (2008a) A New Measure of Financial Openness, Journal of Comparative Policy Analysis, 10, 309-322.

Chinn, M.D., and Ito, H. (2008b) Global Current Account Imbalances: American Fiscal Policy versus East Asian Savings, Review of International Economics, 16, 479-498.

Chinn, M.D., and Prasad, E.S. (2003) Medium-term determinants of current accounts in industrial and developing countries: an empirical exploration, Journal of International Economics, 59, 47-76.

Frankel, J.A., and Romer, D. (1999) Does Trade Cause Growth?, American Economic Review, 89, 379-399.

Gruber, J.W., and Kamin, S.B. (2007) Explaining the global pattern of current account imbalances, Journal of International Money and Finance, 26, 500-522.

La Porta, R., Lopez-de-Silanes, F., Shleifer, A., and Vishny, R.W. (1999) The quality of government, The Journal of Law, Economics, and Organization, 15, 222-279. 
Table 1. Current account regressions with finance and openness indicators

\begin{tabular}{|c|c|c|c|c|c|c|c|c|c|c|}
\hline & \multicolumn{10}{|c|}{ Dependent variable: Current account/GDP } \\
\hline & $(1)$ & $(2)$ & (3) & (4) & (5) & (6) & (7) & (8) & (9) & (10) \\
\hline \multirow[t]{2}{*}{ Gov. Budget Balance/GDP } & 0.156 & 0.123 & 0.139 & 0.171 & 0.150 & 0.142 & 0.112 & 0.114 & 0.102 & 0.098 \\
\hline & 0.97 & 0.78 & 0.82 & 1.18 & 0.99 & 0.97 & 0.73 & 0.69 & 0.65 & 0.63 \\
\hline \multirow[t]{2}{*}{ NFA/GDP (initial) } & 0.006 & 0.010 & -0.012 & 0.051 & 0.030 & 0.045 & 0.017 & -0.018 & 0.005 & 0.008 \\
\hline & 0.11 & 0.19 & -0.24 & 0.81 & 0.53 & 0.68 & 0.30 & -0.34 & 0.10 & 0.14 \\
\hline \multirow[t]{2}{*}{ Old Dependency ratio } & 0.275 & 0.208 & 0.281 & 0.184 & 0.189 & 0.150 & 0.153 & 0.282 & 0.191 & 0.167 \\
\hline & 2.24 & 1.71 & 2.23 & 1.60 & 1.61 & 1.31 & 1.31 & 2.31 & 1.60 & 1.41 \\
\hline \multirow[t]{2}{*}{ Young Dependency ratio } & 0.007 & -0.035 & 0.029 & -0.031 & -0.004 & -0.057 & -0.025 & 0.033 & 0.024 & -0.001 \\
\hline & 0.11 & -0.50 & 0.37 & -0.46 & -0.06 & -0.83 & -0.33 & 0.43 & 0.29 & -0.02 \\
\hline \multirow[t]{2}{*}{ Relative income } & 0.040 & 0.053 & 0.036 & 0.075 & 0.070 & 0.077 & 0.071 & 0.049 & 0.082 & 0.077 \\
\hline & 0.83 & 1.12 & 0.71 & 1.57 & 1.48 & 1.63 & 1.53 & 1.00 & 1.71 & 1.58 \\
\hline \multirow[t]{2}{*}{ Relative income squared } & 0.000 & 0.001 & 0.000 & 0.001 & 0.001 & 0.001 & 0.001 & 0.000 & 0.001 & 0.001 \\
\hline & 0.10 & 0.39 & 0.12 & 0.56 & 0.60 & 0.69 & 0.74 & 0.21 & 0.75 & 0.77 \\
\hline \multirow[t]{2}{*}{ Average GDP growth } & 0.186 & -0.053 & 0.168 & 0.068 & 0.043 & -0.098 & -0.144 & 0.060 & -0.109 & -0.162 \\
\hline & 0.56 & -0.15 & 0.49 & 0.19 & 0.12 & -0.27 & -0.38 & 0.17 & -0.28 & -0.43 \\
\hline \multirow[t]{2}{*}{ Terms of trade volatility } & 0.176 & 0.196 & 0.194 & 0.157 & 0.180 & 0.177 & 0.208 & 0.198 & 0.206 & 0.213 \\
\hline & 2.02 & 2.25 & 1.98 & 2.02 & 2.03 & 2.30 & 2.39 & 2.16 & 2.26 & 2.37 \\
\hline \multirow[t]{2}{*}{ Trade Openness } & - & 0.034 & - & - & - & 0.027 & 0.030 & - & - & - \\
\hline & - & 3.10 & - & - & - & 2.25 & 2.45 & - & - & - \\
\hline \multirow[t]{2}{*}{ Financial Openness } & - & - & 0.321 & - & 0.406 & - & 0.522 & - & 0.436 & 0.497 \\
\hline & - & - & 0.72 & - & 0.88 & - & 1.13 & - & 0.92 & 1.07 \\
\hline \multirow[t]{2}{*}{ Financial Development } & - & - & - & -0.031 & -0.032 & -0.024 & -0.025 & - & -0.034 & -0.028 \\
\hline & - & - & - & -1.54 & -1.59 & -1.12 & -1.17 & - & -1.73 & -1.27 \\
\hline \multirow[t]{2}{*}{ Policy Openness } & - & - & - & - & - & - & - & 0.041 & 0.047 & 0.045 \\
\hline & - & - & - & - & - & - & - & 1.63 & 1.81 & 1.71 \\
\hline \multirow[t]{2}{*}{ Non-policy Openness } & - & - & - & - & - & - & - & - & - & 0.019 \\
\hline & - & - & - & - & - & - & - & - & - & 1.07 \\
\hline $\mathrm{R} 2$ & 0.206 & 0.252 & 0.211 & 0.248 & 0.255 & 0.276 & 0.287 & 0.230 & 0.284 & 0.292 \\
\hline
\end{tabular}

Notes: Pooled least squares estimates. Robust t-statistics in italics. All regressions include a constant, not reported. Number of observations: 114. 
Table A1. Correlations between finance and openness measures

\begin{tabular}{l|ccccc}
\hline & $\begin{array}{c}\text { Financial } \\
\text { Development }\end{array}$ & $\begin{array}{c}\text { Trade } \\
\text { Openness }\end{array}$ & $\begin{array}{c}\text { Financial } \\
\text { Openness }\end{array}$ & $\begin{array}{c}\text { Policy } \\
\text { Openness }\end{array}$ & $\begin{array}{c}\text { Non-policy } \\
\text { Openness }\end{array}$ \\
\hline $\begin{array}{l}\text { Financial Development } \\
\text { Trade Openness }\end{array}$ & 1 & & & & \\
Financial Openness & -0.28 & 1 & & & \\
Policy Openness & 0.22 & -0.10 & 1 & 1 & 1 \\
Non-policy Openness & 0.11 & 0.59 & 0.13 & 0 & \\
\hline
\end{tabular}

Notes: Non-policy Openness is the component of Trade Openness estimated from equation (1). 